\title{
Development and evaluation of 4-(pyrrolidin-3- yl)benzonitrile derivatives as inhibitors of lysine specific demethylase 1 \\ DOI:
}

10.1016/j.bmcl.2017.08.052

\section{Document Version}

Accepted author manuscript

Link to publication record in Manchester Research Explorer

Citation for published version (APA):

Mould, D., Bremberg, U., Jordan, A., Geitmann, M., Mcgonagle, A., Somervaille, T., Spencer, G., \& Ogilvie, D. (2017). Development and evaluation of 4-(pyrrolidin-3-yl)benzonitrile derivatives as inhibitors of lysine specific demethylase 1. Bioorganic and Medicinal Chemistry Letters, 27(20), 4755-4759.

https://doi.org/10.1016/j.bmcl.2017.08.052

\section{Published in:}

Bioorganic and Medicinal Chemistry Letters

\section{Citing this paper}

Please note that where the full-text provided on Manchester Research Explorer is the Author Accepted Manuscript or Proof version this may differ from the final Published version. If citing, it is advised that you check and use the publisher's definitive version.

\section{General rights}

Copyright and moral rights for the publications made accessible in the Research Explorer are retained by the authors and/or other copyright owners and it is a condition of accessing publications that users recognise and abide by the legal requirements associated with these rights.

\section{Takedown policy}

If you believe that this document breaches copyright please refer to the University of Manchester's Takedown Procedures [http://man.ac.uk/04Y6Bo] or contact uml.scholarlycommunications@manchester.ac.uk providing relevant details, so we can investigate your claim.

\section{OPEN ACCESS}




\section{Accepted Manuscript}

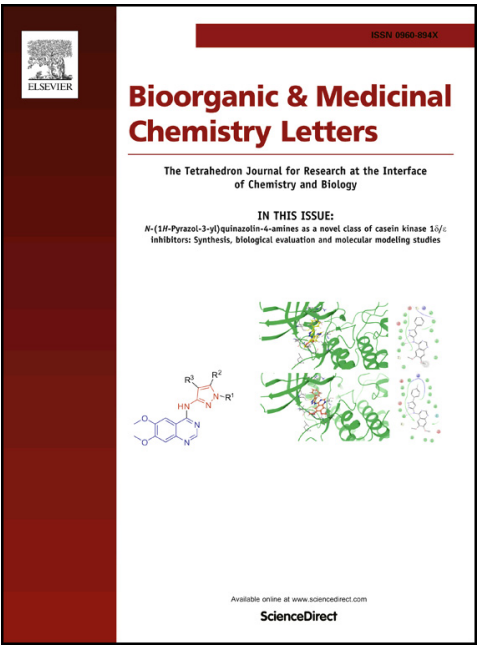

Development and evaluation of 4-(pyrrolidin-3-yl)benzonitrile derivatives as inhibitors of lysine specific demethylase 1

Daniel P. Mould, Ulf Bremberg, Allan M. Jordan, Matthis Geitmann, Alison E. McGonagle, Tim C.P. Somervaille, Gary J. Spencer, Donald J. Ogilvie

PII: S0960-894X(17)30853-3

DOI: http://dx.doi.org/10.1016/j.bmcl.2017.08.052

Reference:

BMCL 25246

To appear in:

Bioorganic \& Medicinal Chemistry Letters

Received Date:

24 July 2017

Revised Date:

21 August 2017

Accepted Date:

23 August 2017

Please cite this article as: Mould, D.P., Bremberg, U., Jordan, A.M., Geitmann, M., McGonagle, A.E., Somervaille, T.C.P., Spencer, G.J., Ogilvie, D.J., Development and evaluation of 4-(pyrrolidin-3-yl)benzonitrile derivatives as inhibitors of lysine specific demethylase 1, Bioorganic \& Medicinal Chemistry Letters (2017), doi: http://dx.doi.org/ 10.1016/j.bmcl.2017.08.052

This is a PDF file of an unedited manuscript that has been accepted for publication. As a service to our customers we are providing this early version of the manuscript. The manuscript will undergo copyediting, typesetting, and review of the resulting proof before it is published in its final form. Please note that during the production process errors may be discovered which could affect the content, and all legal disclaimers that apply to the journal pertain. 


\title{
Development and evaluation of 4-(pyrrolidin-3-yl)benzonitrile derivatives as inhibitors of lysine specific demethylase 1
}

Daniel P. Mould ${ }^{\mathrm{a}}$, Ulf Bremberg ${ }^{\mathrm{c}}$, Allan M. Jordan ${ }^{\mathrm{a}}$, Matthis Geitmann ${ }^{\mathrm{c}}$, Alison E. McGonagle ${ }^{\mathrm{a}}$, Tim C. P. Somervaille ${ }^{\mathrm{b}}$, Gary J. Spencer ${ }^{\mathrm{b}}$, and Donald J. Ogilvie ${ }^{\mathrm{a}}$

${ }^{a}$ Drug Discovery Unit, Cancer Research UK Manchester Institute, University of Manchester, Wilmslow Road, Manchester, M20 4BX, UK

${ }^{\mathrm{b}}$ Leukaemia Biology Laboratory, Cancer Research UK Manchester Institute, University of Manchester, Wilmslow Road, Manchester, M20 4BX, UK

${ }^{c}$ Beactica AB, Uppsala Business Park, Virdings allé 2, 75450, Uppsala, SE

\begin{abstract}
As part of our ongoing efforts to develop reversible inhibitors of LSD1, we identified a series of 4(pyrrolidin-3-yl)benzonitrile derivatives that act as successful scaffold-hops of the literature inhibitor GSK-690. The most active compound, 21g, demonstrated a $K_{\mathrm{d}}$ value of $22 \mathrm{nM}$ and a biochemical $\mathrm{IC}_{50}$ of $57 \mathrm{nM}$. In addition, this compound displayed improved selectivity over the hERG ion channel compared to GSK-690, and no activity against the related enzymes MAO-A and B. In human THP-1 acute myeloid leukaemia cells, $\mathbf{2 1 g}$ was found to increase the expression of the surrogate cellular biomarker CD86. This work further demonstrates the versatility of scaffold-hopping as a method to develop structurally diverse, potent inhibitors of LSD1.
\end{abstract}

\section{Keywords}

epigenetics; LSD1; KDM1A; reversible inhibitor; stem cell differentiation; cancer therapy; epigenetic therapy; acute myeloid leukaemia 
Table of contents graphic
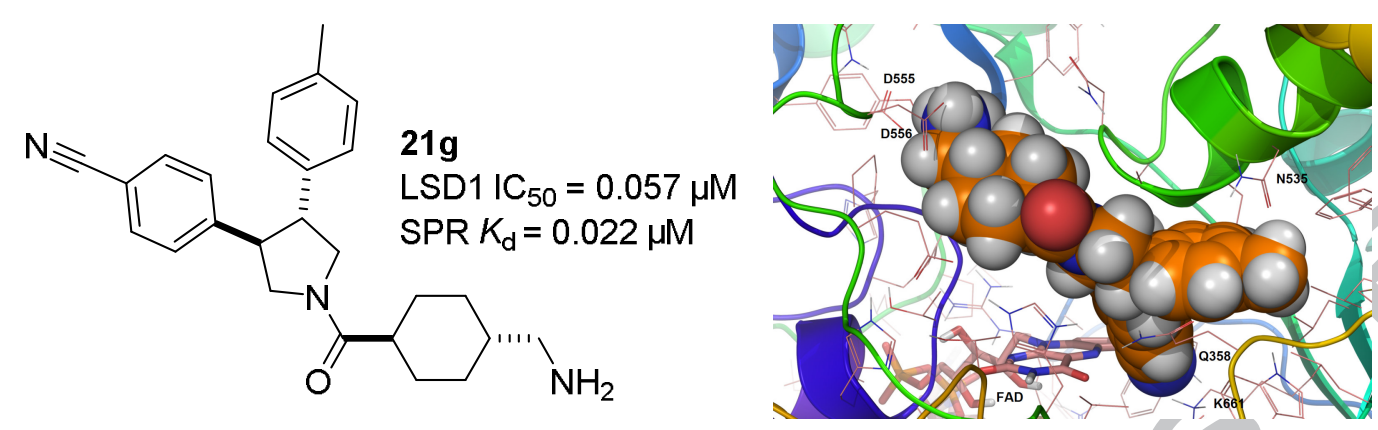

Text:

Lysine specific demethylase 1 (LSD1) has been found to have roles that go far beyond its initially discovered function of removing methyl marks from histone tails via an oxidative demethylation mechanism. ${ }^{1-3}$ The clinical potential of this epigenetic eraser in cancer and associated disease areas has been unravelled, largely as a result of experiments exploiting the use of irreversible LSD1 inhibitors developed from tranylcypromine. In a subset of acute myeloid leukaemia (AML), LSD1 has been shown to be important in the maintenance of leukaemia stem cells and the promotion of a block on differentiation. ${ }^{4}$ Additionally, LSD1 inhibition has been shown to reactivate the all-trans retinoic acid (ATRA) pathway by increasing the expression of myeloid-differentiation genes, suggesting that a combination of LSD1 inhibitor and ATRA may offer a new therapeutic option for AML subtypes that are generally insensitive to ATRA therapy alone. ${ }^{5}$ While tranylcypromine derivatives have facilitated a great deal of research, there is still an unmet need for a variety of reversible tool compounds that display no offtarget pharmacology. ${ }^{6}$

GSK-690 (1, Figure 1) is a versatile start-point for the development of reversible LSD1 inhibitors, however the development of this compound was hindered by a human ether-a-go-go related gene (hERG) liability. ${ }^{7}$ Aromatic scaffold replacements are an attractive and logical way to retain potency while 
moving into novel intellectual property space. ${ }^{8}$ To that end, patents that disclose a number of mono- and bicycle heterocyclic scaffolds that replace the central pyridine ring have recently been disclosed. ${ }^{9-14} \mathrm{We}$ instead looked to focus on scaffold-hops that featured ring systems that were partly or fully saturated. We hypothesised that the decreased lipophilicity and increased flexibility of a saturated core structure may be a valid strategy to try and overcome the persistent hERG liability of $\mathbf{1}$ and related derivatives. ${ }^{15-16}$

An increase in $\mathrm{sp}^{3}$ character has the effect of increasing the molecules 3-dimensional (3D) shape and reducing the aromatic ring count, which have both been noted as important factors in improving the developability of compounds as potential drugs. ${ }^{17-18}$ On the other hand, this approach brings the added complications of potential stereocenters and synthetic challenges of transformations that would be trivial on an aromatic scaffold but remain complex in the timeframe of hit-to-lead development. ${ }^{19}$

Herein, we describe our efforts to identify series of reversible inhibitors with scaffolds containing multiple $\mathrm{sp}^{3}$ centres, and their elaboration and development into potent inhibitors of LSD1 as confirmed by biochemical, surface plasmon resonance (SPR) and cellular biomarker assays with significantly reduced activity against the hERG ion channel.

To investigate the potential of saturated scaffold-hops from compound 1, we begin by using Cresset Spark (Welwyn Garden City, UK) software to identify potential replacements of the pyridine core incorporating $\mathrm{sp}^{3}$ centres at the attachment points of the two aryl groups. This identified two potential isosteric replacements that appeared to be synthetically accessible via cycloaddition reactions, namely $\beta$ lactams and pyrrolidines. From there, we refined the spatial overlap between the scaffold-hops and $\mathbf{1}$ using Cresset Torch to design potential ligands (Figure 1). The cis- $\beta$-lactam diastereomers (2) were predicted to be far more favourable than the trans- $(\mathbf{3})$, as this allows the two aryl groups be oriented in the same plane as modelled by $\mathbf{1}$, whereas in the trans-diastereoisomers the aryl groups are forced out of the plane. Modelling potential pyrrolidine scaffolds on the other hand, the increased flexibility of the fully 
saturated ring system means that it is possible for a trans-diastereoisomer (4) to adopt a conformation where the two hydrogens sit axially, with the aryl rings oriented only slightly out of plane.
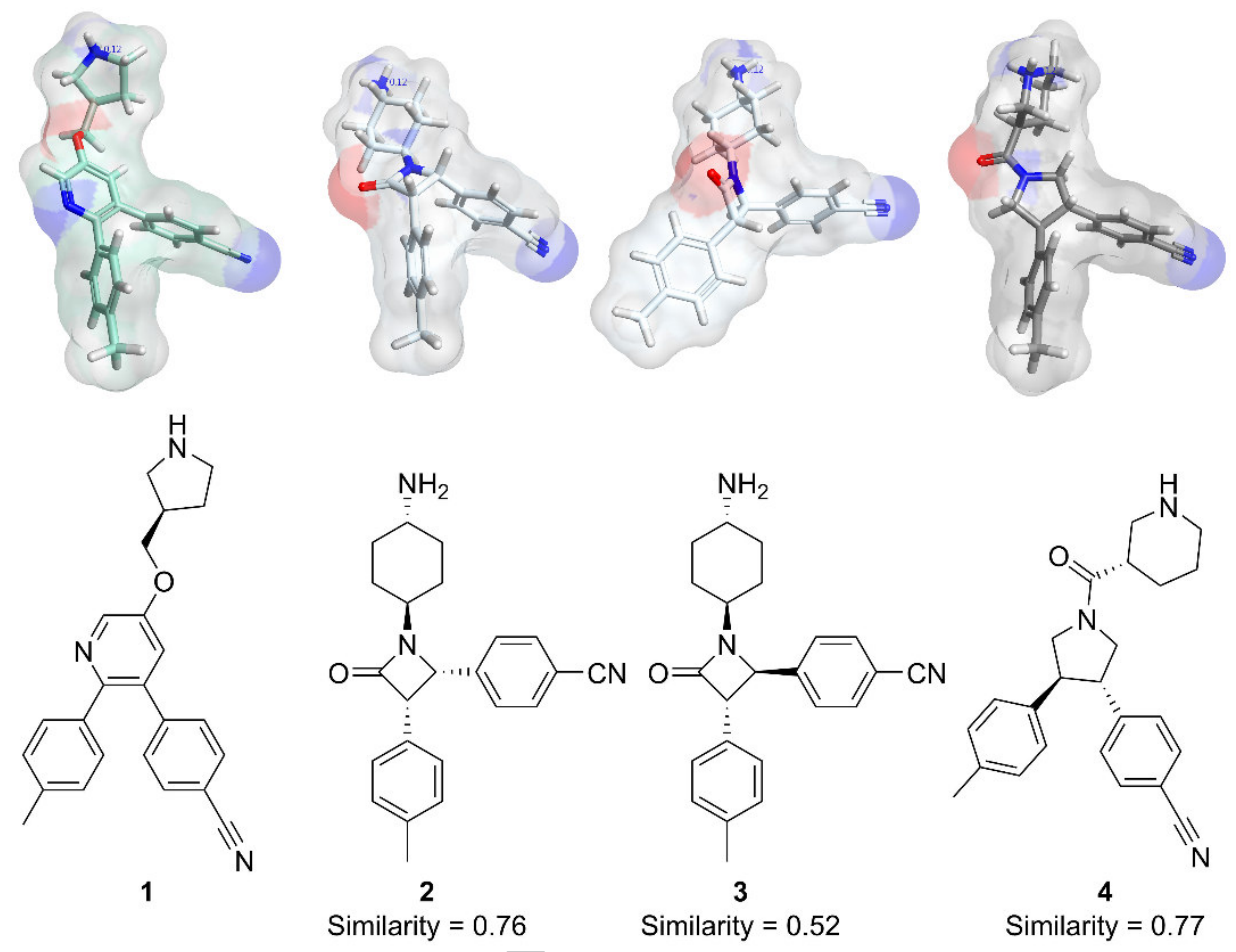

Figure 1. Cresset Torch alignment between 1 and new scaffold designs $2-\mathbf{4}$. A similarity score of $>0.7$ was considered a good score. Absolute stereochemistry indicated.

The $\beta$-lactam core can be constructed via a Staudinger [2+2] cycloaddition reaction between an imine and a ketene which can optionally be formed in situ. We used the method developed by Coulthard and coworkers ${ }^{20}$ which employs propylphosphonic anhydride (T3P) under basic conditions to afford a mixture of diastereoisomers, with the trans- $\beta$-lactam being formed as the major diastereoisomer on similar substrates to the target molecule. After forming imine 6, T3P-mediated cycloaddition with 2-( $p$ tolyl)acetic acid or 2-(4-methoxyphenyl)acetic acid afforded a mixture of diastereometric products in an almost 1:1 ratio. These were separable by preparative HPLC to afford the $c i s$ - and trans-products 7-10 as 
a mixture of enantiomers. The characteristic vicinal coupling of the lactam protons by NMR ( $c i s-J=5.2$ $\mathrm{Hz}$; trans- $J=2.3 \mathrm{~Hz}$ ) allowed for identification of the structure of each product. ${ }^{20}$ These enantiomeric mixtures were tested for their inhibitory activity against LSD1 in biochemical time resolved fluorescent resonance energy transfer (TR-FRET) and biophysical surface plasmon resonance (SPR) assays, as previously reported. ${ }^{16}$ While the trans-diastereoisomers $(\mathbf{8 - 1 0})$ were inactive in both assay formats $\left(\mathrm{IC}_{50}>\right.$ $30 \mu \mathrm{M}$ and $K_{\mathrm{d}}>100 \mu \mathrm{M}$ ), we were encouraged to find that the cis-diastereoisomers, which were predicted to adopt a more favourable conformation to act as an isostere of $\mathbf{1}$, did show modest activity and reversibility against LSD1 by SPR $\left(\mathbf{8} K_{\mathrm{d}}=38 \mu \mathrm{M}, \mathbf{1 0} K_{\mathrm{d}}=53 \mu \mathrm{M}\right)$.
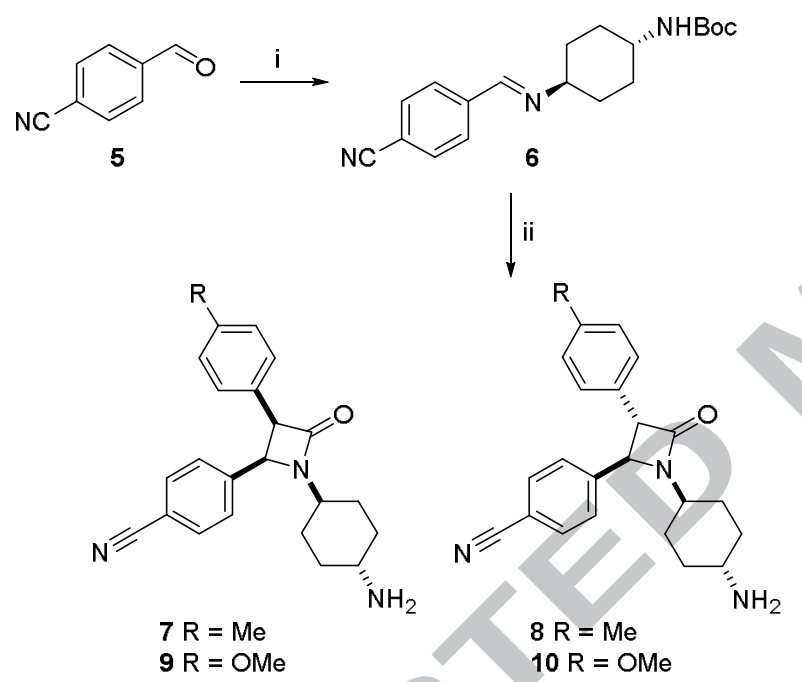

Scheme 1. Synthesis of compounds 7 - 10. Reagents and conditions: i) N-Boc-trans-1,4cyclohexanediamine, MeOH, reflux, 1 h, 78\%. ii) T3P, DIPEA, ( $p$-tolyl)acetic acid $(7,9)$ or 2-(4methoxyphenyl)acetic acid $(\mathbf{8}, \mathbf{1 0})$, chloroform, reflux, 2 h, then TFA, DCM, 1 h, $24-58 \%$ (total of both isomers).

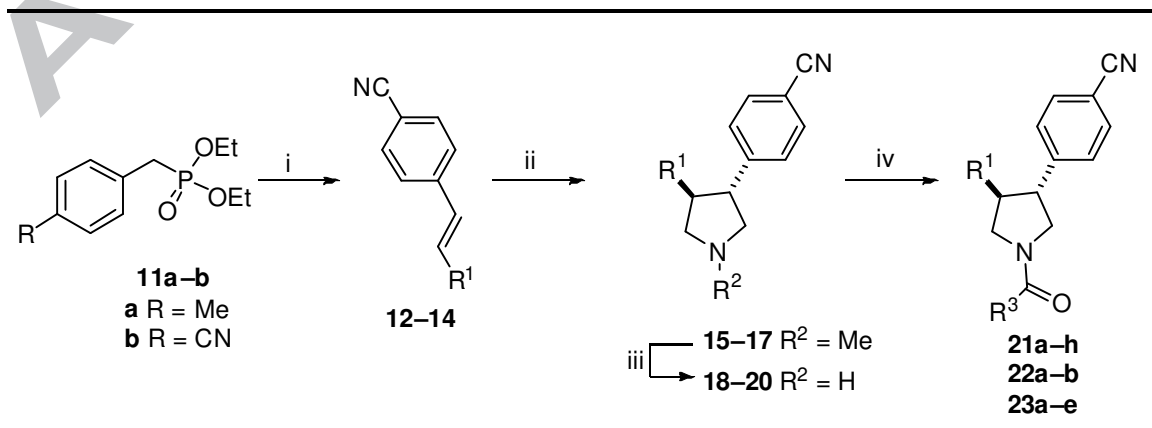


Scheme 2. Synthesis of compounds 21-23. Reagents and conditions: i) 12: 11a, 4-formylbenzonitrile, $\mathrm{KO}^{\mathrm{t}} \mathrm{Bu}, \mathrm{THF}, 0{ }^{\circ} \mathrm{C}$ to rt, $16 \mathrm{~h}, 54 \%$; 13: 11b, 6-methoxynicotinaldehyde, $\mathrm{KO} \mathrm{B}^{\mathrm{B} u}$, THF, $0{ }^{\circ} \mathrm{C}$ to rt, $16 \mathrm{~h}$, 70\%; 14: 1-methyl-1H-indazole-5-carbaldehyde, 11b, KO ${ }^{\mathrm{B} u}$, THF, $0{ }^{\circ} \mathrm{C}, 1 \mathrm{~h}, 91 \%$. ii) trimethylamine oxide, LDA, DMF, $0{ }^{\circ} \mathrm{C}, 1 \mathrm{~h}, 13-52 \%$. iii) 1-Chloroethyl chloroformate, THF, reflux, $1 \mathrm{~h}, 40{ }^{\circ} \mathrm{C}$, then $\mathrm{MeOH}$, reflux, $1 \mathrm{~h}, 85-97 \%$ iv) Appropriate carboxylic acid, COMU, DIPEA, DMF, $1 \mathrm{~h}$, then $4 \mathrm{M}$ $\mathrm{HCl} /$ dioxane, $10-66 \%$.

Historically 3,4-disubstituted pyrrolidines have been constructed by the reaction of alkenes most commonly with azomethine ylide sources such as $\mathrm{N}$-(methoxymethyl)-N(trimethylsilylmethyl)benzylamine in the presence of trifluoroacetic acid. ${ }^{21}$ However, we found this combination of reagents was unable to effect conversion of the stilbene precursors to the cycloaddition product. The trans-pyrrolidines were synthesised via 1,3-dipolar cycloaddition of trans-stilbene precursors with trimethylamine oxide in the presence of excess LDA, as developed by Davoren and coworkers. ${ }^{22}$ This afforded the N-methyl products, which were deprotected by reaction with 1-chloroethyl chloroformate followed by refluxing in methanol. Amide coupling, followed by Boc-deprotection, afforded amines 21a-h, 22a-b and 22a-e.

Pyrrolidines 21a-h were screened against LSD1 by biochemical TR-FRET assay, and we were gratified to observe that this series transferred the spatial and electrostatic similarity to 1 into promising levels of potency (Table 1). Optimisation of the basic centre focussed upon varying the length and flexibility of the linker between the amide and the amine functionalities. Piperidine 21a and trans-cyclohexylamine 21b showed reasonable levels of activity, with sub-micromolar $K_{\mathrm{d}}$ values. From initial results, introduction of a methylene unit between the amide and the cyclohexane looked to offer improved affinity (21c-f). Moving the methylene linker from the amide to the amine led to transexamic acid derivative $\mathbf{2 1 g}$ which displayed low nanomolar activity by both SPR and biochemical assay, and was only $~ 2$-fold less active than $\mathbf{1}$. Methylation of this amine (21h) was poorly tolerated, resulting in a $\sim 4$-fold drop-off in potency 
The patent literature generally deviates away from the $p$-tolyl group, and we were keen to explore replacements that are frequently observed, to see if this would offer an additional route to improve potency (Table 2). The methoxypyridine replacement (23a-b) showed a disappointing 8-15-fold drop-off in potency in comparison to matched pairs 21d and 21f. More successful was replacement with a methylindazole (23a-e), however potency could not be improved further. The matched pair of $\mathbf{2 1 g}$ (23d) showed only a $\sim 2$-fold drop off by SPR. Interestingly, replacing the cyclohexyl motif of 23d with an aromatic system $(\mathbf{2 3 c})$ shows a $\sim 20$-fold decrease in potency, suggesting the importance of a saturated system in this region. 
Table 1. Pyrrolidine amide SAR

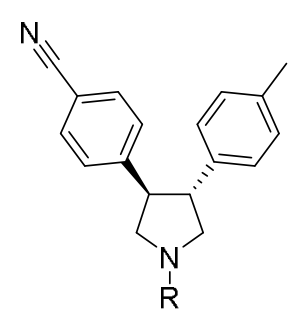

\begin{tabular}{|c|c|c|c|}
\hline Compound & $\mathbf{R}$ & $\mathrm{IC}_{50}(\boldsymbol{\mu M})$ & $\begin{array}{l}\text { SPR } K_{\mathrm{d}} \\
(\mu \mathrm{M})\end{array}$ \\
\hline 1 & & $\begin{array}{l}0.041 \\
(0.015)\end{array}$ & 0.008 \\
\hline $21 \mathrm{a}$ & & $4.2(0.6)$ & 0.61 \\
\hline $21 b$ & & $3.0(0.6)$ & 0.43 \\
\hline 21c & & $0.95(0)$ & 0.19 \\
\hline 21d & & $0.57(0.02)$ & 0.11 \\
\hline $21 \mathrm{e}$ & & $0.82(0.06)$ & 0.12 \\
\hline $21 f$ & & $0.68(0.05)$ & 0.061 \\
\hline $21 g$ & & $\begin{array}{l}0.057 \\
(0.003)\end{array}$ & 0.022 \\
\hline
\end{tabular}


$21 \mathrm{~h}$

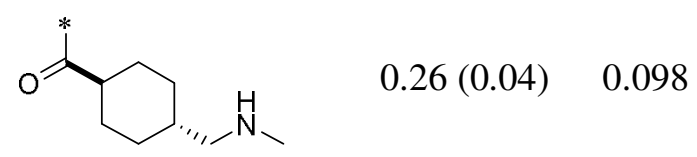

${ }^{\mathrm{a}} \mathrm{IC}_{50}$ and $K_{\mathrm{d}}$ values for selected compounds against the LSD1 enzyme in biochemical and biophysical assays. Standard deviation given in parentheses. $\mathrm{IC}_{50}$ determined from 10-point concentration/effect experiments. Geometric mean of at least two independent experimental determinations given.

Table 2. SAR of $p$-tolyl replacements and amide elaboration

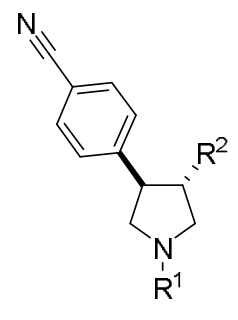

\begin{tabular}{lllll}
\hline Compound & $\mathbf{R}^{1}$ & $\mathbf{R}^{2}$ & $\mathbf{I C}_{\mathbf{5 0}}(\boldsymbol{\mu M})$ & $\begin{array}{l}\mathrm{SPR} K_{\mathbf{d}} \\
(\boldsymbol{\mu} \mathrm{M})\end{array}$ \\
\hline $22 \mathrm{a}$ & & &
\end{tabular}

22b<smiles>CC(=O)CC1CCCNC1</smiles>

$\overbrace{N}^{O} 9.0(0.6)$

$23 \mathbf{a}$<smiles>CC(=O)C1CCC(N)CC1</smiles><smiles>Cc1ccc2c(cnn2-c2ccccc2)c1</smiles>

$4.8(0.2)$

1.4

23b<smiles>CC(=O)C1CCC(N)CC1</smiles><smiles>Cc1ccc2c(cnn2-c2ccccc2)c1</smiles>

$2.6(0.4)$

0.77

23c<smiles>CC(=O)c1ccc(CN)cc1</smiles><smiles>[Y]c1ccc2c(c1)C=NC2=[W]</smiles>

$4.4(0.2)$ 2.0

23d<smiles>CC(=O)C1CCC(CN)CC1</smiles><smiles>[X]c1ccc2c(cnn2-c2ccccc2)c1</smiles>

$0.21(0)$ 0.048 


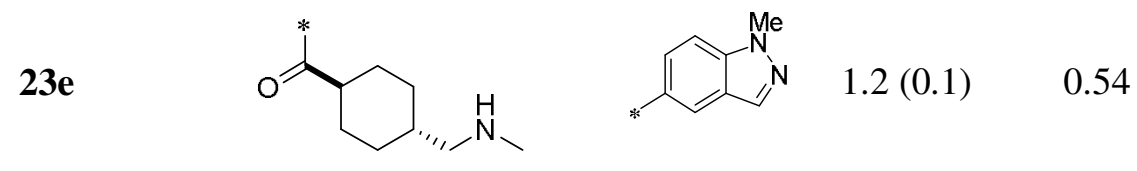

${ }^{\mathrm{a}} \mathrm{IC}_{50}$ and $K_{\mathrm{d}} \overline{\text { values for selected compounds against the LSD1 enzyme in biochemical and biophysical }}$ assays. Standard deviation given in parentheses. $\mathrm{IC}_{50}$ determined from 10-point concentration/effect experiments. Geometric mean of at least two independent experimental determinations given.

Using knowledge of the binding mode of $\mathbf{1}$ bound to LSD1, ${ }^{7}$ we used Glide (Schrödinger, New York, USA), ${ }^{24}$ to model both enantiomers of $\mathbf{2 1 g}$ into the crystal structure of LSD1 bound to the reversible ligand tetrahydrofolate (PDB: 4KUM). ${ }^{25}$ There was no significant difference between the docking scores of each enantiomer, however we are yet to separate the enantiomers and test this experimentally. The predicted binding mode of $(3 R, 4 R)-\mathbf{2 1}$ is given in Figure 2. The compound was predicted to made two key hydrogen bonding interactions. The nitrile forms a hydrogen bond with Lys661, with the basic centre being directed towards Asp555 and Asp556. Targeting these acidic residues appears to be a valuable strategy and has been seen with other structurally distinct series of reversible inhibitors. ${ }^{26-27}$ The widevariety of scaffold hops from 1 appears to be due to the lack of close contacts between the core (in this case the pyrrolidine ring) and the protein. Thus, this central portion of the molecule could be used as a versatile handle to improve DMPK. The $p$-tolyl groups points into a hydrophobic channel formed by Ile356, Leu677, Leu693, and Trp695. 


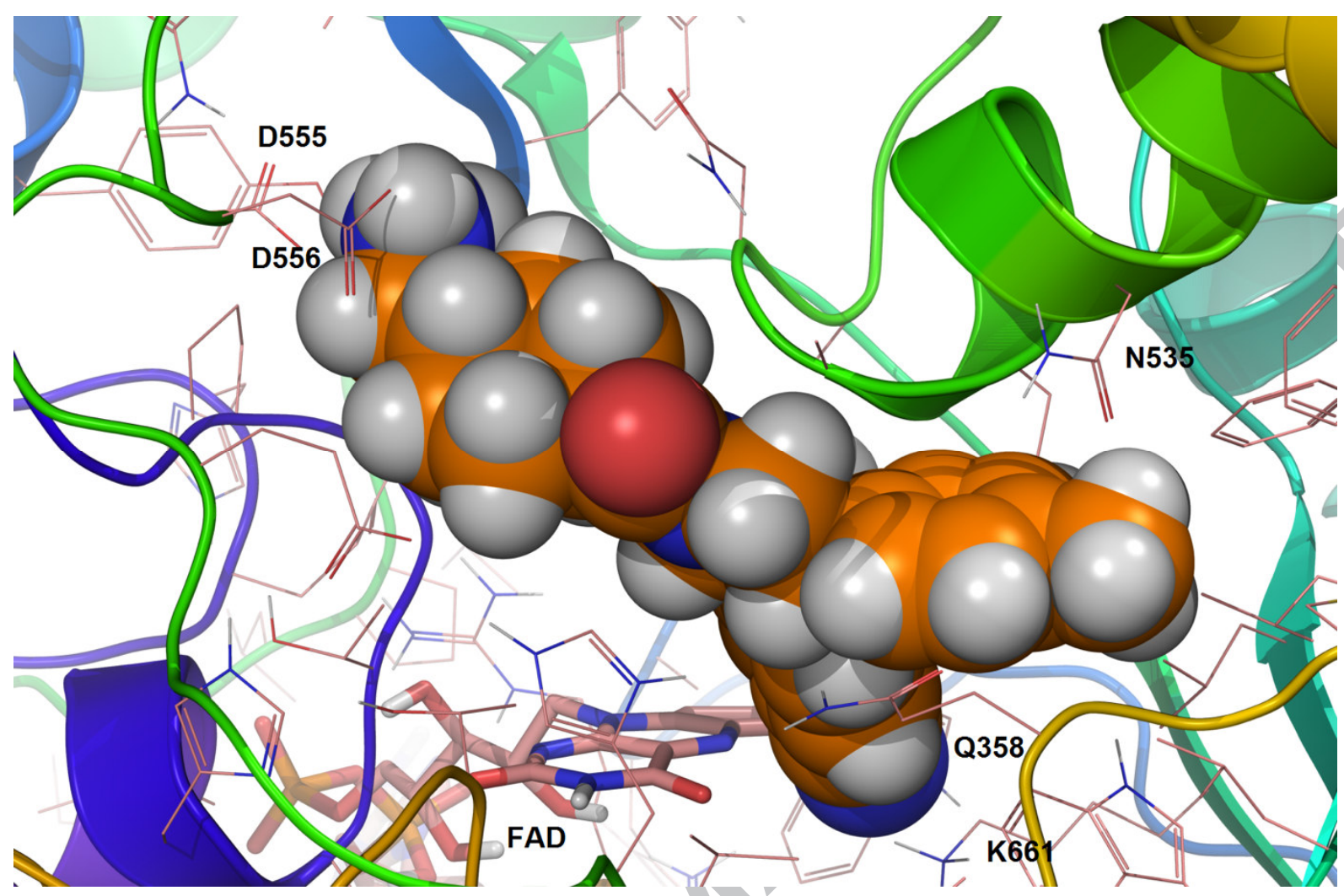

Figure 2. Predicted binding mode of the $(3 R, 4 R)$-enantiomer of compounds $\mathbf{2 1 g}$ (in the LSD1 active site (4KUM). Visualised in PyMOL.

Compound 21g demonstrated excellent selectivity over both MAO-A and MAO-B ( $\left.\mathrm{IC}_{50}>25 \mu \mathrm{M}\right)$, and improved selectivity over the hERG ion channel compared to $\mathbf{1}\left(\mathbf{2 1 g} \mathrm{IC}_{50}=12.1 \mu \mathrm{M}, \mathbf{1} \mathrm{IC}_{50}=3.2 \mu \mathrm{M}\right){ }^{28}$ The increase in expression levels of the cell surface marker CD86 in THP-1 acute myeloid leukaemia cells as a response to LSD1 inhibition has been used to provide a robust cellular assay format (Figure 3 ). ${ }^{27}$ We tested our most active derivative, $\mathbf{2 1 g}$, alongside $\mathbf{1}$, and a previously described hydroxypyrazole based inhibitor of LSD1 (24). ${ }^{16}$ All three compounds induced the expression of CD86 after $48 \mathrm{~h}$ in a dose dependent manner, as expected, although $\mathbf{2 1 g}$ displayed marginally less activity than $\mathbf{1}$.

In summary, we have designed a series of 4-(pyrrolidin-3-yl)benzonitrile derivatives that demonstrate potent activity against LSD1 in biochemical assays and by SPR. The most potent derivative, $\mathbf{2 1 g}$, demonstrates comparable levels of cellular activity to other previously described reversible inhibitors of 
LSD1, complete selectivity against related monoamine oxidase enzymes and shows improved selectivity in comparison to $\mathbf{1}$ against the hERG ion channel. This profile makes $\mathbf{2 1 g}$ a useful cell-active tool compound to further explore the role of LSD1 in cells. This series represents the first example of a potent saturated scaffold-hop from $\mathbf{1}$, and is an excellent start-point for further optimisation.

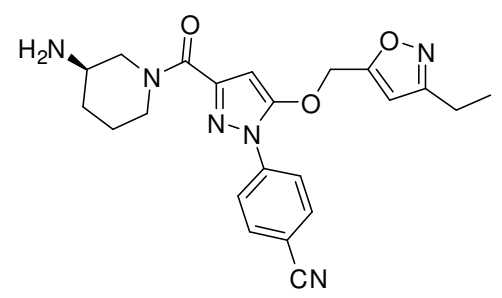

24

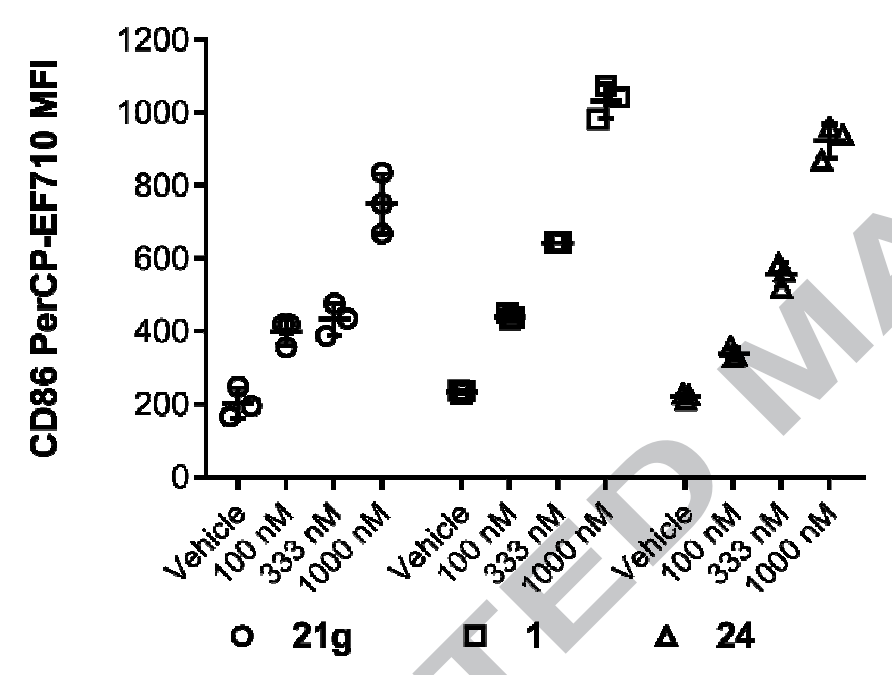

Figure 3. Top: Structure of compound 24. Bottom: CD86 assay results for compounds $\mathbf{2 1 g} \mathbf{1}$ and $\mathbf{2 4}$. The upper detection limit of this assay was $\sim 1300$ mean fluorescence intensity (MFI) units as determined by treatment of cells with $250 \mathrm{nM}$ of the irreversible inhibitor OG-86. Error bars display standard deviation of each mean value. 


\section{Acknowledgments}

This work was supported by Cancer Research UK (Grants C5759/A12328, C480/A11411, C5759/A17098 and C5759/A02901). Additional support was provided to DPM by the Society of Chemical Industry through a Messel Scholarship. We are thankful to Bohdan Waszkowycz for his assistance with Glide. In vitro pharmacokinetic and hERG data was provided by Cyprotex Discovery (Macclesfield, UK). Images of protein-ligand docking were captured within the PyMOL Molecular Graphics System, Version 1.7.6.2. (Schrödinger, LLC, New York).

\section{Notes and References}

Tim Somervaille has ongoing research collaborations with Oryzon Genomics and consults for Imago Biosciences. The other authors declare no competing financial interest.

1. Shi Y, Lan F, Matson C, et al. Cell. 2004;119(7): 941-953.

2. Shi Y-J, Matson C, Lan F, Iwase S, Baba T, Shi Y. Mol Cell. 2005;19(6): 857-864.

3. Amente S, Lania L, Majello B. BBA Gen. Reg Mech. 2013;1829(10): 981-986.

4. Harris WJ, Huang X, Lynch JT, et al. Cancer Cell. 2012;21(4): 473-487..

5. Schenk T, Chen WC, Göllner S, et al. Nat Med. 2012;18(4): 605-611

6. Mould DP, McGonagle AE, Wiseman DH, Williams EL, Jordan AM. Med Res Rev. 2015;35(3): 586-618.

7. Johnson NW. The Identification of GSK2879552, a Mechanism Based Irreversible Inhibitor of the Histone Lysine Demethylase LSD1. XXIV EFMC International Symposium on Medicinal Chemistry. Manchester, UK; 2016.

8. Sun H, Tawa G, Wallqvist A. Drug Disc Today. 2012;17(7-8): 310-324.

9. Chen Y, K., Kanouni T, Nie Z, Stafford JA, Veal JM, Sung LM. WO2016004105. Celgene Quanticel Research Inc.; 2016. 
10. Chen YK, Kanouni T, Kaldor SW, Stafford JA, Veal JM. WO2015089192. Celgene Quanticel Research Inc.; 2015.

11. Chen YK, Kanouni T, Nie Z, Stafford JA, Veal JM, Sung LM. WO2016003917. Celgene Quanticel Research Inc.; 2016.

12. Liangxing W, Courter JR, Chunhong H, et al. US20160009720. Incyte Corporation; 2016.

13. Liangxing W, Konkol LC, Lajkiewicz N, et al. US20160009712. Incyte Corporation; 2016.

14. Liangxing W, Xiaozhao W, Wenqing Y, Zhang C. US20160009711. 2016.

15. Moorthy NS, Ramos MJ, Fernandes PA. SAR QSAR Environ Res. 2012;23(5-6): 521-536.

16. Mould DP, Bremberg U, Jordan AM, et al. Bioorg Med Chem Lett. 2017;27(14): 3190-3195.

17. Ritchie TJ, Macdonald SJF. Drug Disc Today. 2009;14(21-22): 1011-1020.

18. Lovering F, Bikker J, Humblet C. J Med Chem. 2009;52(21): 6752-6756.

19. Ritchie TJ, Macdonald SJF, Young RJ, Pickett SD. Drug Disc Today. 2011;16(3-4): 164-171.

20. Coulthard G, Unsworth WP, Taylor RJK. Tetrahedron Lett. 2015;56(23): 3113-3116.

21. Terao Y, Kotaki H, Imai N, Achiwa K. Chem Pharm Bull. 1985;33(7): 2762-2766.

22. Davoren JE, Gray DL, Harris AR, Nason DM, Xu W. Synlett. 2010;2010(16): 2490-2492.

23. Friesner RA, Banks JL, Murphy RB, et al. J Med Chem. 2004;47(7): 1739-1749.

24. Luka Z, Pakhomova S, Loukachevitch LV, Calcutt MW, Newcomer ME, Wagner C. Protein Sci. 2014;23(7): 993-998.

25. Vianello P, Sartori L, Amigoni F, et al. J Med Chem. 2017;60(5): 1673-1692.

26. Sartori L, Mercurio C, Amigoni F, et al. J Med Chem. 2017;60(5): 1693-1715.

27. MAO and hERG inhibition assays were performed by Cyprotex (Macclesfield, U.K.).

28. Lynch JT, Cockerill MJ, Hitchin JR, Wiseman DH, Somervaille TCP. Anal Biochem. 2013;442(1): 104-106. 


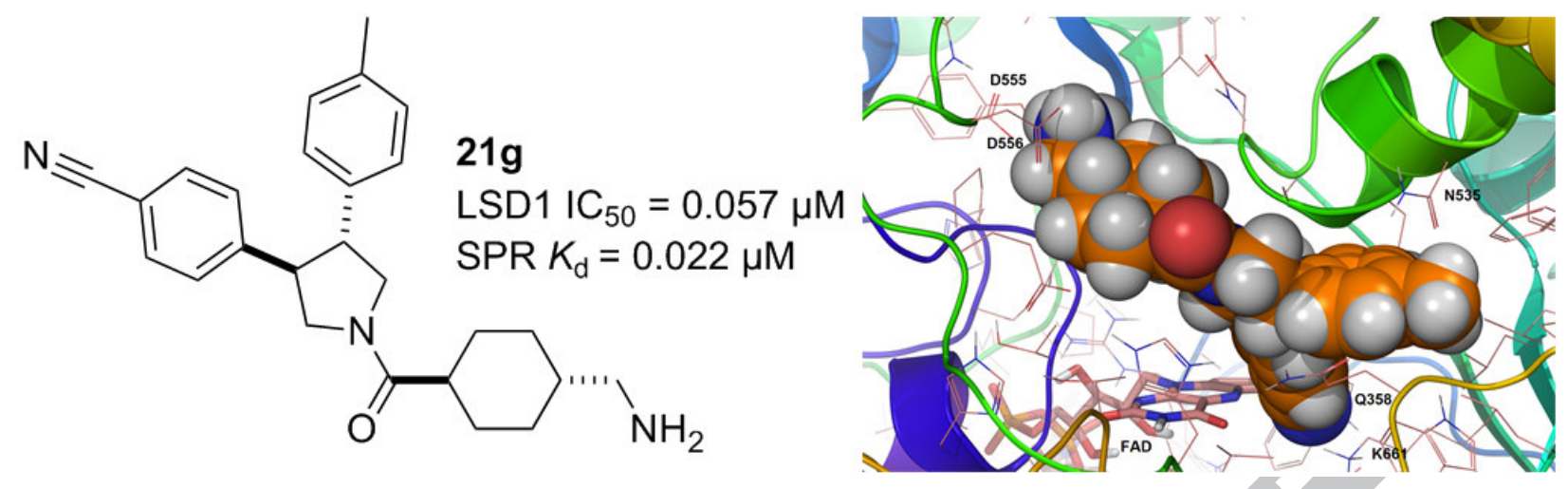

